\title{
The Role of Institution Related to Conservation Area of Merbabu Mountain National Park in Boyolali District
}

\author{
Bernadus Agus Hartanto ${ }^{1, *}$, Jafron Wasiq Hidayat ${ }^{2}$, and Bambang Waluyo Hadi Eko Prasetiyono ${ }^{3}$ \\ ${ }^{1}$ Magister Program of Environmental Science, School of Postgraduate Studies, Diponegoro University, Semarang - Indonesia \\ ${ }^{2}$ Faculty of Science and Mathematics, Diponegoro University, Semarang - Indonesia \\ ${ }^{3}$ Faculty of Animal and Agricultural Sciences, Diponegoro University, Semarang - Indonesia
}

\begin{abstract}
Conservation areas including Mount Merbabu National Park (MMNP) that have social, economic and ecological benefits both for the local and global environment need attention and support not only for MMNP office but also for the integration of the roles of parties related institutionally. The objective of the present study was to obtain the information about the involvement and integration of the roles of related institutions to support the conservation of the MMNP area in Boyolali District. The method is used literature review. The results shows that the role of various related institutions in MMNP conservation still varied. The local government, community institutions and other institutions do not have a continuous program in supporting conservation MMNP. Integration of related institutional roles in supporting the preservation of MMNP area through the compilation of conservation regulations that were followed up with the village regulation at buffer zone MMNP, Extension of MMNP conservation to all levels of society, especially at the school level, Integration of tourism development within and outside the MMNP area, Integration of community empowerment programs in and around the MMNP area, Mitigation of MMNP disturbances and disasters integratively.
\end{abstract}

Keywords: Merbabu Mountain National Park; institutional; conservation; Boyolali.

\section{Introduction}

Preservation of forest areas, especially national parks, is the fifteenth target in the aim of the Sustainable Development Programs (SDGs) launched by the United Nations Agency (UN) to be achieved by 2030 [1]. Balancing the goals of sustainable development of nature conservation and the provision of environmental services is a major challenge for the management of the current national park [2].

Protection and management of conservation areas, especially national parks, are very much needed considering several things which include: First, the existence of conservation areas, especially national parks as the last bastion of biodiversity preservation determined based on the purpose of preserving existing ecosystem types, Second, is managed most intensively where one unit of area is managed by one management unit (technical implementing unit: National Park Office), Third, Multi-function, the application of zoning systems in the management of the area allows the functioning of several functions (Law No. 5 of 1990). Conservation areas are sources of hydrology, water catchments, water suppliers for watersheds, guardians and biodiversity developers for flora and fauna, providers of environmental services and ecotourism [3].
This decade the real conditions in the field illustrate that the average conservation area, especially national parks in Indonesia, has intangible disturbances of deforestation and degradation which have an impact on the lack of flora and fauna biodiversity in lowland tropical rainforest ecosystems that can threaten the sustainability of the national park area. Changes in land use in the period 2001-2013 were a reduction in the area of forests, grasses and mixed plantations, followed by an increase in the area of bushes, settlements, and fields. The rate of deforestation within the MMNP area is $2.29 \%$ per year or equivalent to $87 \mathrm{ha} /$ year [4]. Another problem in the management of national park areas is the limited human resource management of the park so that the impact on efforts to overcome regional security disturbances is not optimal either due to natural conditions or human activities including land and forest fires, illegal abuse of natural resources, hunting of animals wild and regional encroachment [5].

Law No. 5 of 1990 concerning the conservation of living natural resources and its ecosystem states that the conservation of living natural resources constitutes the management of living natural resources which are carried out wisely to ensure the continuity of their supply while maintaining and improving the quality of diversity and value.

Various laws governing biodiversity conservation have been implemented, such as Law No. 5 of 1990

\footnotetext{
$\overline{\text { * Corresponding author: bernadagusanto@gmail.com }}$
} 
concerning Biodiversity Conservation and its Ecosystem and Government Regulation No. 7 of 1999 concerning Preservation of Plants and Animals. But its implementation is still difficult to do [6] because the roles and responsibilities between related institutions have not been well-integrated and coordinated. Synchronizing regional development in regions with management of protected areas including conservation areas is a must [7]. The actual conditions of the role and coordination of cross-sectoral institutions in conservation have an impact on the formulation and implementation of the policies of the relevant government organizations that should be carried out in one coordination bond based on their respective functions [8].

Similar studies mention the need for integration of conservation programs to adjust policies and management strategies [2,9]. National Park Management requires an integrated planning approach based on transdisciplinary research and the involvement of all stakeholders [10] and institutional management must consider strategic planning in regulations to address the diversity of demands to achieve conservation goals [11]. Good local government has the authority to intervene in achieving the objectives of social justice and protection of conservation areas [12], although institutional changes limit governance adaptation and have removed the sense of responsibility for maintaining national park resources [13].

The transformation of the role of national park management institutions that are concentrated in area managers from government based management to collaborative management has been running especially after the issuance of Forestry Ministerial Regulation no. P.19 / Menhut-II / 2004 concerning collaboration in the management of nature reserves and natural conservation areas. The implementation of a new management system that involves many parties with various interests becomes a challenge, so that the implementation of a potential stakeholder-based collaboration system in the management of national parks that has been, is being carried out and is very important as learning and improving the management of the national park area in the future [14].

In connection with the above, this study aims to obtain information on the role of relevant institutions to support the conservation of the Merbabu Mountain National Park (MMNP), which is expected to be useful in the management of MMNP in Boyolali Regency.

\section{Material and Method}

\subsection{Study Area}

The study was conducted in Boyolali District which is one of the administrative areas of Mount Merbabu National Park (MMNP). The object of the research includes related institutions in the management and preservation of the TNGMb conservation area, namely the MMNP Office as the area manager and various
Boyolali District Government agencies specifically related to MMNP namely Bappeda, LH Office, Agriculture Office, Youth and Sport Service Office, Livestock and Fisheries Office, BPBD, Ampel District and Selo District, community institutions and other related institutions, both formal and informal, that are around and have interactions with the MMNP area.

The area of MMNP based on the Decree of the Forestry Minister Number: SK.3623 / Menhut-VII / KUH / 2014 dated May 6, 2014, was 5,820.49 ha, of which the administrative area of Boyolali Regency was 2,274 hectares which included 2 Districts namely Selo and Ampel and surrounded by 13 buffer villages [15].

\subsection{Data Collection}

Data obtained from the literature study method and or review of some literature (literature review). This research is a literature study by examining the latest scientific literature in the range of the years 2007-2018 that has been documented in various forms such as books, journals, archives and other light bookkeeping related to the study. A literature review is not only meaningful in reading literature, but rather in depth and critical evaluation of previous research on a topic. Literature Review is a critical and in depth evaluation of previous research [16].

\subsection{Data Analysis}

The results of qualitative data in the form of literature studies and/or literature review are then summarized, analyzed and synthesized critically and deeply. The results of the summary, analysis and synthesis are then described in a descriptive and conclusions drawn.

\section{Result and Discussion}

In Law 32/2019 it is stated that the control and/or environmental damage in the context of the preservation of environmental functions are carried out by the Government, regional government and the person in charge of the business or activity in accordance with their respective authorities, roles, and responsibilities. Every person and society has the right to protect and manage the environment in accordance with the laws and regulations. Conservation is a vulnerable thing, where environmental management is not beneficial if it does not involve the community with basic knowledge capital of environmental management so that involving the community that understands the principle of sustainability will result in effective and efficient environmental management [17]. Environmental management in conservation areas requires the support of diverse disciplines, multistakeholder approaches, supported by consistent and adaptive policies by the government starting from the central, provincial, district, sub-district, village, village, mukim, to the site level, with assistance that is consistent and appropriate targets from CSOs, local universities, local champions, activists, 
and resort staff. Weak and ineffective cross-ministerial support, across sectors, private sector participation, support from civil society, community leaders, religious leaders, traditional leaders, non-governmental organizations, environmental activists, scientists from local universities cause various problems in the conservation area cannot be resolved completely [7].

Preservation of conservation areas in the future is expected to be carried out in an integrated manner according to Forestry Minister Regulation No. P19 / Menhut-II/ 2004 concerning Collaborative Management. Each relevant institution can participate because the implementation of conservation areas will cover the interests of many parties and various institutions. Coordination and consolidation between related institutions certainly need to be improved to create integrated programs and roles.

Based on research on various institutions involved in MMNP conservation, namely:

Table 1. Institutions related to conservation MMNP

\begin{tabular}{|c|c|}
\hline No & Institutions \\
\hline 1 & Merbabu Mount National Park (MMNP) Office \\
\hline 2 & $\begin{array}{l}\text { Regional Government of Boyolali Regency } \\
\text { a) Regional Planning and Development Agency } \\
\text { (Bappeda) } \\
\text { b) Environmental services (DLH) } \\
\text { c) Office of Youth, Sports and Tourism } \\
\text { d) Office of Public Works and Spatial Planning } \\
\text { e) Office of Cooperatives and Micro, Small and } \\
\text { Medium Enterprises } \\
\text { f) Office of Agriculture } \\
\text { g) Office of Livestock and Fisheries } \\
\text { h) Regional Disaster Management Agency } \\
\text { (BPBD) and Search and Rescue (SAR) } \\
\text { i) Ampel District } \\
\text { j) Selo District } \\
\text { k) Regional Water Company (PDAM) }\end{array}$ \\
\hline 3 & $\begin{array}{l}\text { Village Society Institution } \\
\text { a) Ampel District (Village of Ngagrong, Candisari, } \\
\text { Ngargoloko, Sampetan, Ngadirojo, Jlarem) } \\
\text { b) Selo District (Village of Selo, Senden, } \\
\text { Tarubatang, Jeruk, Samiran, Jrakah, Lencoh) } \\
\text { c) Youth Organization } \\
\text { d) PKK } \\
\text { e) Forum Rembug Desa } \\
\text { f) Customary Institutions } \\
\text { g) Religious Institutions } \\
\text { h) Village Conservation Model Group (MDK) } \\
\text { i) Fire Care Society (MPA) } \\
\text { j) Village Alert Team } \\
\text { k) Polhut Partner Society (MMP) }\end{array}$ \\
\hline 4 & $\begin{array}{l}\text { Environmental \& Environmental Conservation } \\
\text { Observers Institution } \\
\text { a) Nature Lovers Group (KPA) } \\
\text { b) Conservation Cadres Group } \\
\text { c) Farmer Groups } \\
\text { d) Merapi Merbabu Community } \\
\text { e) Merbabu Care Community } \\
\text { f) People's Seed Garden (KBR) }\end{array}$ \\
\hline 5 & $\begin{array}{l}\text { Water Conservation Social Institution } \\
\text { a) Water Care Forum (Forpela) } \\
\text { b) Water Consumer Groups }\end{array}$ \\
\hline
\end{tabular}

\begin{tabular}{|l|l|}
\hline & $\begin{array}{l}\text { c) Clean Water Management Group } \\
\text { d) Paguyuban Banyu Seminar } \\
\text { e) Community Based Water Supply and Sanitation } \\
\text { (PAMSIMAS) }\end{array}$ \\
\hline 6 & $\begin{array}{l}\text { Other institutions } \\
\text { a) PPL Extension } \\
\text { b) District PNPM }\end{array}$ \\
\hline
\end{tabular}

Source: Various literature data

Based on qualitative research and assessment of literature studies on various institutions related to conservation MMNP both in and around it shows the role of each institution still varies from ecological, economic, social and legal aspects.

Furthermore, the role information of each institution can be described as follows:

\section{Mount Merbabu National Park Office}

Based on Law No. 5 of 1990 concerning Natural Resource Conservation and its Ecosystem, MMNP as one of nature conservation areas has duties and functions, namely the protection of life support systems, preservation of plant and animal species diversity and their ecosystems, and sustainable use of natural resources and ecosystems.

This is then explained in the main tasks, namely the implementation of conservation of living natural resources and their ecosystems, as well as management of the national park area based on applicable laws and regulations [15]. In carrying out these basic tasks, the MMNP Office carries out its role functions including Inventory of potential, protection and security of the area, forest fire control, preservation of species, utilization of environmental services, socialization of counseling, development of community love and community empowerment in and around the area.

\section{Regional Government of Boyolali Regency}

The role of the Regional Government in supporting the preservation of the MMNP area in Boyolali Regency is represented by related agencies as presented in Table 1 . In the provincial spatial policy, Boyolali Regency is included in the provincial strategic area called SUBOSUKA WONOSRATEN (Surakarta, Boyolali, Sukoharjo, Karanganyar, Wonogiri, Sragen, and Klaten). In this case the area of Merbabu Mountain has a very important role, including: (1) Protected areas for hydroorological protection; (2) Water conservation and recharge zones, including springs (Ampel and Selo); (3) Nature Conservation Areas, natural tourism (Selo); and (4) Areas prone to landslides [18].

Mount Merbabu National Park which is adjacent to Mount Merapi National Park has natural tourism potential that has not been developed optimally. Boyolali Regency Government has placed Selo and Ampel as the development of natural tourism and become a Solo-SeloBorobudur (SSB) tourism network. Potential tourism objects in the SSB line include the New Selo viewing post, Ketep viewing post, agro tourism in Selo and Kopeng, and Mount Merbabu climbing tours [19], in addition to Mount Merbabu is a favorite of climbers, whose hiking trails are through Selo support tourism 
sector in Boyolali so it needs to be integrated. In the spatial policy of Boyolali Regency, Selo and Ampel Subdistricts whose territory borders MMNP are included in the Development Region III Unit, where Ampel and Selo Sub-Districts, among others, function as food crop development [18].

The Boyolali District Government policy that can synergize with the management of MMNP includes: (1) protecting water catchments and water sources for household and agricultural irrigation purposes; (2) supporting livestock development; (3) supporting the development of the Selo tourist area; (4) supporting programs to improve community welfare and food security; (5) involving the community in management through a pattern of collaboration or partnership; (6) became a pioneer in the rehabilitation and restoration of damaged forest areas [19].

\section{Village Community Institutions}

The role of community institutions is a central position in supporting the conservation of the MMNP area. The community institutions directly come into contact with the community who are active and utilizing forest and land resources at MMNP both directly and indirectly. The community institutions around the MMNP area, namely 13 Penyangga Village (table 1) generally consist of: consisting of village heads, bodies, customary institutions, religious institutions, youth organizations, PKK and other village groups or forums.

Village heads, community leaders, and Pam Swakarsa members have a large role in providing conservation awareness to the community through community meetings and farmer group meetings. In planning the management of MMNP the community has a consultative role, which is limited to providing advice that is not necessarily implemented by MMNP. In managing their own areas, communities through groups in the village are involved in forest rehabilitation and community empowerment activities. In the supervision of the MMNP area, the people who are members of the pamswakarsa group, the community of the forest police partner and the community who care about the fire carry out security independently and provide counseling [20].

\section{Conservation Observer Institutions}

These institutions have an important role in the preservation of the MMNP area where the focus is on various activities, such as the Merbabu Care Community through planting/ reforestation as well as plant maintenance reforestation. Clean trash action on the hiking trail and socialization to climbers is also an activity of Nature Lovers who helped maintain the $\mathrm{TNGMb}$ area, while also playing a role in conservation education.

\section{Water Conservation Social Institution}

This institution plays a role in efforts to conserve water which is an important necessity in the daily life of the people of the slopes of Mount Merbabu. Efforts are made to safeguard water catchment areas within the
MMNP area and provide information on the importance of preserving MMNP.

\section{Other Institutions}

The role of other institutions in supporting the preservation of varicated areas depends on their respective fields. Extension agents play a role in socializing and counseling both agriculture, livestock and forestry itself. Merapi Merbabu and Community. PNPM on district which has a role in advancing villages, especially around the area, can help optimize the needs of the village community while maintaining the sustainability of the MMNP area, in line with community empowerment programs.

\section{Conclusion}

The role of various institutions in MMNP conservation is still varied and not well integrated. Coordination and consolidation between related institutions certainly need to be improved to create integrated programs and roles. Roles that can be integrated among them:

1 Preparation of a conservation law that was followed up by the conservation village regulation

2 Counseling and outreach the importance of MMNP conservation to all levels of society, which can become local content at the school level

3 Integration of tourism development within and outside the MMNP area

4 Integration of community empowerment programs especially in and around MMNP

5 Mitigation of MMNP regional disturbances and disasters integratively

\section{References}

1. U. Nations, Transforming our world: the 2030 agenda for sustainable development. sustainabledevelopment.un.org (2016)

2. S. Sriarkarin and C. Lee, Integrating multiple attributes for sustainable development in a national park, Tour. Manag. Perspect. 28, 1, pp. 113-125 (2018)

3. W. D. Nugroho, E. Larasati, and H. Purnaweni, Evaluasi Penerapan Prinsip Pembangunan Berkelanjutan Dalam Pembangunan di Kabupaten Boyolali, 9, pp. 2008-2013 (2012)

4. M. Alkaf, K. Munibah, and O. Rusdiana, Model Spasial Perubahan Penggunaan Lahan di TN Gunung Merbabu dan Daerah Penyangganya, 16, 1, pp. 43-50 (2014)

5. Wahyuni and Mamonto, Persepsi Masyarakat Terhadap Taman Nasional dan Sumberdaya Hutan: Studi Kasus Blok Hutan Aketajawe, Taman Nasional Aketajawe Lolobata, 2, 1, pp. 1-16 (2012)

6. E. Sutrisno, T. Sulastri, and A. F. Sheilla, Implementasi Kebijakan Konservasi Hutan Untuk Pelestarian Lingkungan Hidup, Hukum Lingkungan dalam Sistem Kebijaksanaan Pembangunan Lingkungan Hidup: 1-16 (2011) 
7. Wiratno, Sepuluh Cara Baru Kelola Kawasan Konservasi di Indonesia: Membangun "Organisasi Pembelajar, Jakarta: Kementerian Lingkungan Hidup dan Kehutanan (2018)

8. M. U. H. Ansar, Peran dan Koordinasi Lembaga Lintas Sektoral Dalam Konservasi Sumber Daya Air, Institut Pertanian Bogor (2009)

9. W. Kuswanda and M. Bismark, Pengembangan Strategi Konservasi dan Peran Kelembagaan Dalam Pelestarian Orangutan Sumatera, 4, 6, pp. 627-643 (2007)

10. G. Kelboro and T. Stellmacher, Protected areas as contested spaces: Nech Sar National Park, Ethiopia, between 'local people', the state, and NGO engagement, Environ. Dev., 16, pp. 63-75 (2015)

11. S. He, L. Gallagher, Y. Su, L. Wang, and H. Cheng, Identification and assessment of ecosystem services for protected area planning: A case in rural communities of Wuyishan national park pilot, Ecosyst. Serv., 31, pp. 169-180 (2018)

12. J. $\mathrm{Wu}, \mathrm{Y} . \mathrm{Hu}, \mathrm{T}$. Liu, and Q. He, Value capture in protected areas from the perspective of commonpool resource governance: A case study of Jiuzhai Valley National Park, China, Land use policy, 79, pp. 452-462, (2018)

13. L. Maia, L. Kris, and B. Hans, Science of the Total Environment Towards a new model for the governance of the Weerribben-Wieden National Park, Sci. Total Environ., 648, pp. 56-65 (2019)

14. A. Winara and A. S. Mukhtar, Potensi Kolaborasi Dalam Pengelolaan Taman Nasional Teluk Cenderawasih di Papua, Penelit. Hutan dan Konserv. Alam, 8, 3, pp. 217-226 (2011)

15. Balai TNGMb, Statistik Balai Taman Nasional Gunung Merbabu Tahun 2017. Boyolali: Balai Taman Nasional gunung Merbabu (2018)

16. H. Meekosha and R. Shuttleworth, What's so ' critical 'about critical disability studies?, 15, 1, pp. 47-76 (2009)

17. A. Soeroso, Konservasi Lingkungan Kawasan Berbasis Manajemen Pembangunan Lingkungan, J. Ekon. Pembang., 12, 1 (2007)

18. BAPPEDA Boyolali, Rencana detail tata ruang (RDTR) Kabupaten Boyolali (Draf laporan antara), Boyolali (2009)

19. H. Gunawan, M. Bismark, and H. Krisnawati, Kajian Sosial Ekonomi Masyarakat Sekitar Sebagai Dasar Penetapan Tipe Penyangga Taman Nasional Gunung Merbabu, Jawa Tengah ( Socio Economic Assessment of Surounding Communities for the Basis of Buffer Zone Establishment in Mount Merbabu National Park, Ce, Penelit. Hutan dan Konserv. Alam, 10, 2, pp. 103-119 (2013)

20. Y. Sadono, Peran Serta Masyarakat dalam Pengelolaan Taman Nasional Gunung Merbabu di Desa Jeruk Kecamatan Selo , Kabupaten Boyolali, 9, 1, pp. 53-64 (2013) 